\title{
Os acervos da ditadura na mesa de montagem ${ }^{1}$ The collections of the dictatorship on the assembly table
}

Anita Leandro | Universidade Federal do Rio de Janeiro Professora da ECO/UFRJ, doutora em cinema, autora de diversos artigos sobre montagem e realizadora de Retratos de identificação (Brasil, 2014, 72'), filme em torno dos acervos da ditadura, premiado no

Cachoeira.Doc e no Festival latino-americano de Trieste.

\section{Resumo}

Esse artigo apresenta os resultados de uma pesquisa de imagens nos arquivos da ditadura brasileira, para a realização de um filme documentário histórico. As estratégias políticas de acesso aos documentos do período e os procedimentos estéticos desenvolvidos na montagem para a valorização desses acervos são, aqui, analisados, com o intuito de extrair dessa experiência empírica ensinamentos sobre a escrita da história no cinema.

Palavras-Chave: Imagens da ditadura; filme de arquivos; Retratos de identificação.

\section{Abstract}

This article presents the results of an image search in the archives of the Brazilian dictatorship, in order to make with a view to making a historical documentary film. The political strategies for gaining access to documents of from the period and the aesthetic procedures developed while editing the film in order to value these collections are analyzed here, with the aim of drawing lessons about writing history in the cinema, from this empirical experience

Keywords: Images of the Brazilian dictatorship; archive-based filmmaking; Identification Photos. 
Num país em que uma memória coletiva sobre o passado ainda não foi suficientemente elaborada, como é o caso do Brasil em relação à ditadura militar, qual seria o papel das imagens documentais na construção das narrativas históricas sobre esse período? Há, nos arquivos brasileiros, centenas de milhares de fotografias de presos políticos produzidas pelas agências de repressão. Com a recente lei de acesso à informação, esses acervos começam timidamente a deixar os arquivos para entrar no espaço sociocultural brasileiro, terreno de intensa disputa pela verdade histórica sobre um período marcado por mortes, desaparecimentos e tortura. No contexto atual, de impunidade dos crimes do passado e de ampliação das políticas de extermínio, como a montagem cinematográfica pode trazer à tona os documentos da história, criando para esses materiais novas formas de visibilidade, complementares àquelas já encontradas nos livros?

A divulgação das imagens da ditadura exige, hoje, do documentarista, uma tríplice tomada de posição em relação a esses materiais. Antes de tudo, é necessário se lançar numa disputa pelas imagens, ou seja, pelo direito de acesso a esses documentos, considerados durante muito tempo, segredo de Estado. Juntase a isso a exigência de uma disputa com as imagens, ou seja, a favor delas, apreendendo-as como objetos, ao mesmo tempo, estéticos e políticos, irredutíveis, por essa razão, ao papel de mera ilustração de conteúdo histórico. E, por fim, é preciso ainda ao cinema saber mediar a disputa inevitável que se estabelece entre as imagens, na mesa de montagem, quando se procede ao cruzamento das diferentes fontes documentais sobre o período. Analisaremos, aqui, essas tomadas de posição do documentarista em relação aos arquivos, partindo dos resultados de uma investigação realizada junto aos acervos das agências de repressão, para o documentário Retratos de identificação (Anita Leandro, 2014, 73 min), filme construído em torno de documentos fotográficos provenientes, em sua maioria, do antigo DOPS da Guanabara. ${ }^{2}$

Nesse documentário, as fotografias produzidas pela polícia foram abordadas em sua dimensão testemunhal, como protagonistas da história. Tínhamos a intuição de que, estudadas com atenção, elas poderiam revelar aspectos do dispositivo de controle que as produzira. Grande parte do material fotográfico reunido na pesquisa para o filme era, até então, desconhecida, inclusive por parte da Comissão Nacional da Verdade e dos próprios pesquisadores desse período, mais fortemente interessados pelas informaçóes contidas nos documentos textuais. A montagem do filme foi, então, pensada com o objetivo de socializar uma documentaçáo cujo acesso ainda era bastante limitado, meio século depois do golpe militar.

Em função da história a ser contada - a morte de dois estudantes de medicina, Chael Schreier, sob tortura, e Maria Auxiliadora Lara Barcellos, que suicidou-se no exílio - foi feito, primeiramente, um levantamento das diversas fontes documentais existentes: fotografias e documentos textuais produzidos pela repressão, entrevistas atuais com sobreviventes e testemunhos de refugiados brasileiros, filmados no Chile em 1971. A reuniáo de todo esse material na mesa de montagem deu origem a uma narrativa histórica em que as imagens de arquivo são mostradas em sua materialidade documental. Além da opção por contar um capítulo restrito da história da ditadura, focado em acontecimentos 
diretamente relacionados à confrontação de quatro pessoas com a polícia, procuramos expor os documentos como objetos singulares e oferecidos, enquanto tais, à apropriação pública.

Buscamos nos procedimentos da montagem formas de valorização da dimensão probatória do material encontrado. Graças à montagem, presente em todas as etapas da pesquisa - da reunião das fontes documentais à montagem propriamente dita, passando pelo registro dos testemunhos orais -, as imagens da repressão, abordadas como personagens da história, puderam retornar ao palco dos acontecimentos políticos, como uma questáo atual. Havia, na origem do projeto, a ambição de fazer com que o filme funcionasse como um "arquivo de bolso", capaz de tornar a documentação disponível náo apenas ao pesquisador, mas a qualquer espectador interessado pela construção de uma memória histórica sobre a ditadura.

\section{A disputa pelas imagens}

O início da disputa pela elaboração de uma narrativa da história a partir das fotografias policiais se confunde com a própria origem dessas imagens e com os objetivos para os quais elas foram produzidas. São imagens extirpadas a ferro e fogo aos prisioneiros, muitas vezes em meio a sessóes de tortura em que alguns deles acabaram mortos, como é o caso do militante da VAR-Palmares, Chael Charles Schreier, torturado e fotografado ao dar entrada no DOPS da Guanabara, poucas horas antes de ser levado para a PE da Vila Militar do Rio de Janeiro, onde seria assassinado, na mesma noite da prisão.

Muitas das fotografias de polícia do período da ditadura foram tiradas durante interrogatórios, à revelia das pessoas nelas identificadas. $\mathrm{O}$ capuz utilizado no rosto do interrogado durante as sessóes de tortura, era retirado para fazer a foto e recolocado logo em seguida, conforme relato de ex-presos políticos entrevistados durante essa pesquisa. É assim que muitos prisioneiros aparecem nas fotos despenteados, feridos, ensanguentados e, no caso dos homens, muitas vezes sem camisa ${ }^{3}$.

A maior parte do acervo fotográfico das agências de repressão brasileiras é composta por fotografias de plano aproximado, à altura da cintura, do busto ou, principalmente, do ombro, que serviam para compor o cadastro dos prisioneiros. $\mathrm{O}$ enquadramento aproximado colocava em evidência sinais fisionômicos marcantes e dava um rosto ao que a repressão chamava de "inimigo interno", expressão que aparece em vários documentos oficiais, em referência aos cidadãos que opunham resistência ao regime. A fotografia se prestava à identificação desse inimigo. Reproduzida em cartazes, ela participava do terrorismo de Estado, na difusão de propaganda política e na caçada aos combatentes procurados pela polícia. As fotografias de polícia serviam, ao mesmo tempo, como convite à delação e instrumento de controle, humilhação e amedrontamento. Nos cartazes da repressáo, distribuídos em larga escala em todo o país, elas se vinham se somar a uma outra imagem, ideológica, destilada no imaginário popular, a do "subversivo", o "procurado". Aliás, no primeiro desses cartazes, as alcunhas de "terroristas assassinos", "procurados", "foragidos", estampadas em vermelho e em 
caixa alta, são atribuídas indistintamente a oito pessoas de organizaçóes e graus de envolvimento diferentes na ação política, indo de Marighela e dos comandantes Lamarca e Espinosa, aos militantes Chael Schreier e Eremias Delizoikov, ambos estudantes (foto 1, Acervo DOPS/GB, APERJ). Esse último, um jovem secundarista de 17 anos de idade, seria assassinado em seguida, "por engano", com mais de 30 tiros, durante cerco da equipe do capitão Guimarães ao ex-sargento Nóbrega, militar dissidente que figurava no mesmo cartaz que o estudante. ${ }^{4}$ As fotografias participavam, assim, de uma campanha bem mais ampla de perseguição e de diabolização das esquerdas. Em seu livro sobre os acervos fotográficos produzidos pelo DEOPS de São Paulo entre 1930 e 1945, Fernanda Torres Magalhães mostra como essa imagem do "subversivo", do "elemento indesejável”, foi historicamente sendo confirmada e construída de maneira gradativa nas fotografias de polícia, antes de ser naturalizada e "incorporada ao discurso da sociedade civil” (2008, p. 28). Na ocasião do golpe de 1964, esse imaginário já vinha, então, sendo alimentado há pelo menos três décadas.

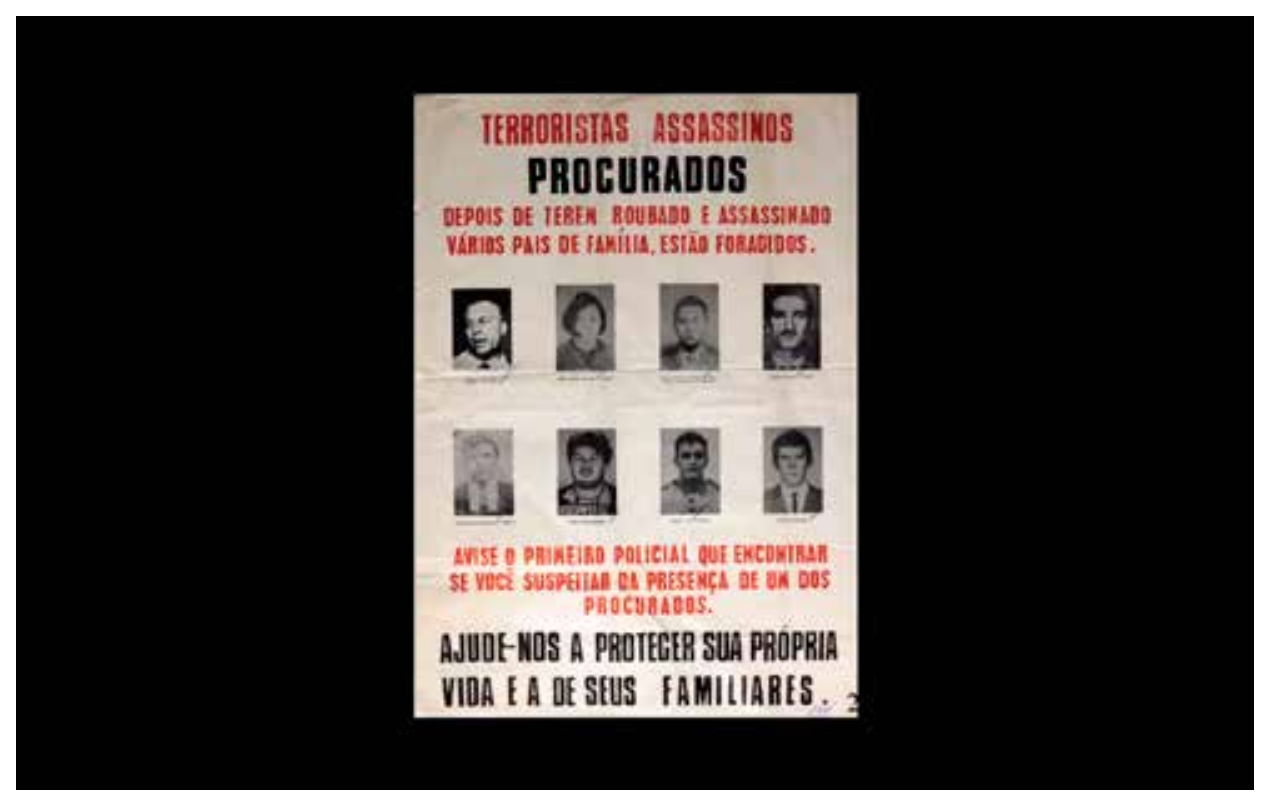

Foto 1, Acervo DOPS/GB, APERJ

No organograma do vasto aparato repressivo, o serviço de fotografia é um suporte importante para as equipes de "busca ostensiva", como eram chamados os grupos de investigação e captura, e também para as equipes de tortura. Em um testemunho registrado para o filme Retratos de identificação, Antônio Roberto Espinosa, preso no Rio de Janeiro em novembro de 1969, em companhia de Chael Schreier e Maria Auxiliadora Lara Barcellos, conta que, ao chegarem ao DOPS, um policial jogara sobre a mesa um pacote de fotografias, dizendo já saber tudo sobre eles. Essas fotos, que figuram na sequência de abertura do filme, haviam sido tiradas às escondidas naquele mesmo dia por um policial que seguira Maria Auxiliadora pelas ruas do Rio de Janeiro e de Niterói, de 8 horas da manhã até às oito da noite, pouco antes da prisão dos três, no aparelho em que moravam, em Lins de Vasconcelos, periferia do Rio. A imagem colabora, assim, em interrogatórios, cujos métodos incluem todo tipo de violação dos direitos humanos: estupro, pau de arara, choques elétricos, fome, sede, frio, isolamento, 
estouro de tímpanos, simulação de execução e tortura com animais (cáes bravios, cobras, ratos, baratas). A imagem participa de um processo de re-identificaçáo e re-subjetivação do prisioneiro por parte do Estado. Para tornar públicas essas fotografias de cadastro de prisioneiros, feitas sobretudo para serem arquivadas, o cinema precisa entrar numa disputa política pelas imagens da repressáo, de forma a mostrar sua outra face.

Essas fotografias permaneceriam, durante muito tempo, confinadas nas delegacias e escritórios das agências de repressão. Mais tarde, quando começaram a ser transferidas para os arquivos públicos, elas se mantiveram inacessíveis até 1990 aos historiadores e até 2012 aos demais cidadáos. ${ }^{5}$ Essas imagens passam, assim, por um segundo controle, uma vez que, durante muito tempo, o direito de acesso a elas nos foi negado. Até hoje, muita coisa ainda se encontra em poder das forças armadas, que se recusam a depositar nos arquivos públicos parte considerável da documentação do período da ditadura. Há, ainda, sonegação de documentos por parte de instituiçóes-chave no desvendamento de alguns crimes, como é o caso do Hospital Central do Exército. ${ }^{6}$ Além disso, muitos documentos ainda continuam inacessíveis, em arquivos privados ou sob controle das forças armadas. Em novembro de 2012, o coronel reformado Júlio Miguel Molinas Dias, chefe do DOI-CODI por três décadas, foi assassinado em Porto Alegre, numa suposta tentativa de assalto. Em sua casa foram encontrados diversos documentos. ${ }^{7}$ Em abril de 2014, um outro coronel, Paulo Malhães, ex-agente do Centro de Informação do Exército, também foi assassinado em condições semelhantes, num suposto assalto à sua casa, apenas um mês depois de prestar depoimento à Comissáo Nacional da Verdade sobre a morte e o desaparecimento do corpo do deputado federal Rubens Paiva. ${ }^{8}$ Nos dois casos, a imprensa e as mídias sociais levantaram a suspeita de queima de arquivo.

A esse duplo controle - do prisioneiro fotografado e do acesso posterior aos documentos - junta-se ainda o fato desses acervos terem sido triados, destruídos e pilhados pela própria polícia, antes de serem levados para os arquivos. E quando as imagens das agências de repressão chegam, finalmente, à mídia, aos telejornais, ao documentário, elas são ainda submetidas a um último processo de controle e de pilhagem: reduzidas na montagem ao papel de ilustração de um conteúdo histórico, como geralmente acontece, a imagem é destituída de sua forma, de sua materialidade e de seu valor probatório, tornando-se, enfim, totalmente inofensiva. Retirar dos arquivos as fotografias produzidas pela polícia durante a ditadura engaja, por consequência, a montagem cinematográfica numa outra disputa pela narrativa histórica, desta vez, com as imagens, ou seja, ao lado delas, de maneira solidária em relaçáo à fragilidade desse tipo de documento e à gravidade do silêncio que ele encerra.

\section{A disputa com as imagens}

A fotografia contém um testemunho silencioso, que a montagem precisa querer ouvir, o que demanda uma certa generosidade da escuta por parte do cinema. Nos arquivos, os documentos não são apenas mudos, "eles são também órfãos" (RICEUR, 2000, p. 213). Ao contrário do testemunho 
oral, que se dirige a alguém (ao historiador, ao documentarista), o documento "não tem destinatário designado" (idem). Os arquivos "dependem dos cuidados de quem tem a competência para questioná-los e, assim, defendê-los, socorrê-los, dar-lhes assistência” (ibid).

Os arquivos têm uma dimensão lacunar e dão acesso apenas a fragmentos de uma história ainda a ser escrita. Mesmo quando há um grande volume de documentos, como é o caso dos acervos da ditadura, trata-se, ainda assim, de sobras do passado. Os prisioneiros eram transferidos de uma cidade para outra e interrogados por diferentes serviços de informação, o que implicou numa dispersão dos documentos. Hoje, para recuperar a história da passagem de um militante pela prisão é preciso, às vezes, consultar vários arquivos, em diferentes estados. Além da dispersão geográfica dos acervos, por critérios de preservação as fotografias foram posteriormente separadas pelos arquivistas dos documentos textuais a elas relacionados. A montagem pode reunir novamente essas fontes documentais que a própria trajetória do documento ou do prisioneiro se encarregou de separar. Vejamos um exemplo de como a montagem, atenta às lacunas da história, pode adotar uma postura solidária ao documento.

Em 1971, em Santiago do Chile, alguns dos 70 militantes brasileiros trocados pelo embaixador suíço Eugênio Bucher, sequestrado pela guerrilha, deram entrevistas para duas equipes de filmagem que realizavam, naquele momento, dois dos primeiros documentários sobre a tortura no Brasil: Não é hora de chorar (Luiz Alberto Sanz e Pedro Chaskel, Chile, 1971) e Brazil: a Report on Torture (Saul Landau e Haskell Wexler, EUA, 1971). ${ }^{9}$ Entre os entrevistados dos filmes de Sanz-Chaskel e de Landau-Wexler está Maria Auxiliadora Lara Barcellos, que explica, de maneira detalhada, as diferentes formas de tortura a que fora submetida no DOPS da Guanabara e na PE da Vila Militar do Rio de Janeiro. Maria Auxiliadora se suicidaria mais tarde em Berlim, durante o exílio, em 1976, o que torna as entrevistas filmadas em 1971 documentos raros. As falas de Maria Auxiliadora existentes nos dois filmes são retomadas quase que integralmente em Retratos de identificaçâo. A montagem as coloca em diálogo com duas outras testemunhas vivas (Antônio Roberto Espinosa e Reinaldo Guarany) e com duas séries de fotografias localizadas no acervo Polícias Políticas do APERJ. Essas séries foram produzidas em diferentes momentos da prisão de Maria Auxiliadora. A primeira delas foi feita em novembro de 1969, no ato da prisão, ao dar entrada no DOPS. Nessas fotos, ela aparece vestida, em plano aproximado cintura, de frente e de perfil. A segunda série foi produzida um ano depois, em dezembro de 1970, durante o exame de corpo de delito a que foram submetidos os 70 prisioneiros trocados pelo embaixador suíço, fotos em que ela aparece nua, de corpo inteiro, de frente, de costas e de perfil esquerdo e direito. A fala de Maria Auxiliadora rememora fatos de extrema violência e era preciso que a montagem se colocasse à altura da gravidade do seu discurso. A montagem não podia, simplesmente, enfatizar o horror contido nem sua narração, se servindo das fotografias de polícia como apoio. Tampouco seria aceitável amenizar esse horror, reduzindo as fotografias de polícia à ilustração do que a testemunha dizia. A montagem de 2014 deveria se oferecer como o lugar de um encontro, enfim, possível entre a fala de uma 
sobrevivente, filmada em 1971, e os documentos relacionados à sua prisão, produzidos entre 1969 e 1970. Havia, assim, quatro tempos históricos a serem considerados pela montagem.

Maria Auxiliadora conta, nessas entrevistas, as torturas de ordem sexual que sofrera, nua, diante de vários homens. Os policiais ameaçavam estuprá-la com um cassetete; tentavam obrigá-la a fazer sexo coletivo com Chael e Espinosa; abriam e fechavam uma tesoura sobre seus mamilos, ameaçando cortá-los; colocavam uma pistola no seu ouvido; batiam-lhe a cabeça contra a parede e davam-lhe inúmeras bofetadas, para deformar o seu rosto: "Eles diziam, mesmo, que iriam me mudar o rosto", diz a testemunha num trecho do filme de Landau. Aproximar sua fala das fotografias tiradas no DOPS, ainda vestida, era uma tarefa relativamente simples, uma vez que o documento fotográfico fora produzido no dia da prisão, quando ela sofreu torturas de que fala nos filmes. Encontramos, inclusive, nos acervos do SNI, a cópia de uma outra série de fotos desse mesmo dia, tirada durante a tortura, em que Maria Auxiliadora aparece de frente e de perfil, ainda vestida, mas com o rosto já muito inchado e com um curativo na cabeça. Essas fotografias do momento da prisão provavam o que ela dizia, ao mesmo tempo em que seu testemunho esclarecia a situaçáo mostrada nas fotos.

A dificuldade, para a montagem, estava em conseguir aproximar suas falas sobre a torturas sexuais sofridas na noite da prisão das fotos do exame de corpo de delito, tiradas no momento da saída de Maria Auxiliadora para o exílio. Ela falava de algo acontecido em 1969 e a montagem a mostraria numa fotografia policial de 1970, nua, mas em outra circunstância. Esconder esse anacronismo entre o documento sonoro e o documento visual seria reduzir a fotografia de Maria Auxiliadora nua à ilustração de sua fala, enfatizando o conteúdo de forma tão desnecessária quanto imoral. Mostrá-la nua, quase quarenta anos depois de sua morte, sem um comentário dela que nos autorizasse a fazê-lo, equivaleria a despi-la novamente. Por outro lado, as fotografias do exame de corpo de delito continham vestígios daquilo que Maria Auxiliadora dizia. Embora as fotos dela nua tivessem sido tiradas no momento da saída da prisão, quando, a princípio, já não havia mais a tortura física, vê-se, no entanto, nelas, as marcas que os suplícios deixaram na prisioneira: a crispação dos lábios; o olhar triste, desviado da objetiva e sempre pousado no chão; os ombros nus e curvados; os pés descalços no cimento; a parede de azulejos brancos que serve de pano de fundo, com a data do exame médico (23/12/1970). Optamos, então, por fazer recortes nessas fotos, de forma a evitar a exibição da nudez de Maria Auxiliadora, mas, também, procurando mostrar, com os closes no documento, aspectos imperceptíveis da situação fotografada, como a data no azulejo, a expressão do rosto, a delicadeza das mãos, a marca das correias dos chinelos sobre seus pés descalços. Para evitar a ilustração, a montagem opta, assim, por levar o documento à beira da ficção, trazendo à tona, por meio da decupagem, uma poética do testemunho visual da fotografia. No fragmento reverbera aquilo que é dito e a fotografia funciona como um contraponto visual para o arquivo oral (foto 2, Acervo DOPS/GB, APERJ). Apresentados como registros anacrônicos que são, as fotografias e o arquivo oral aparecem como documentos singulares, historicamente datados e irredutíveis um ao outro, com suas respectivas lacunas e potências narrativas próprias. 


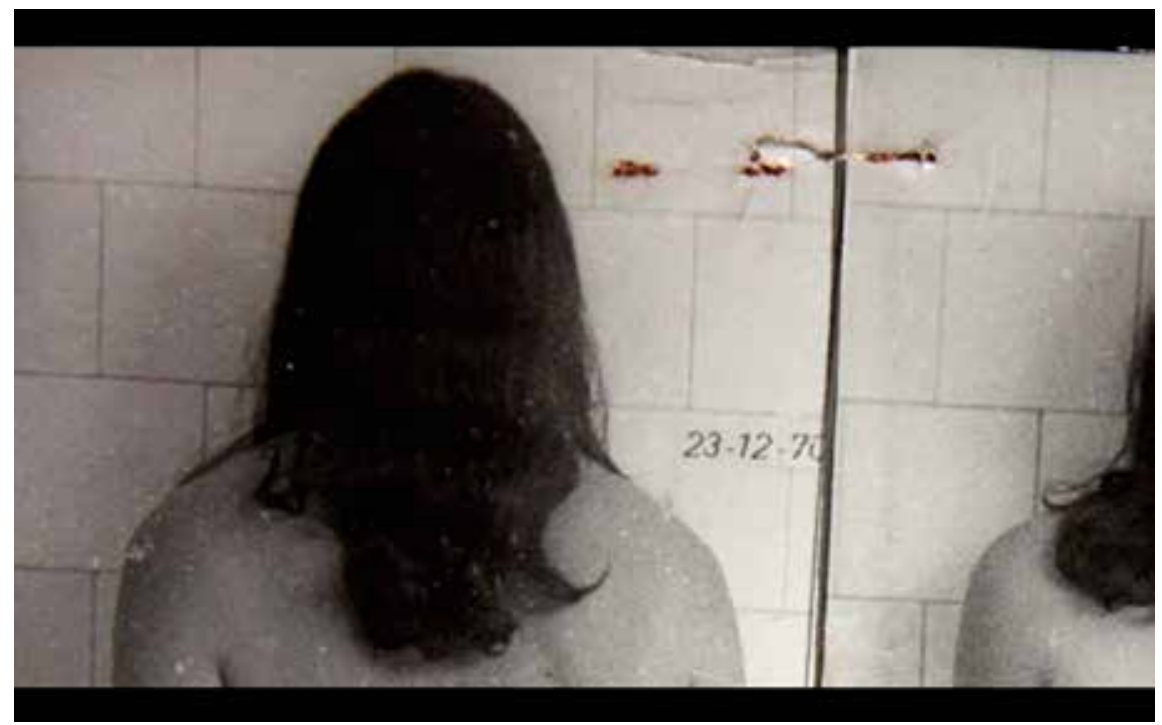

Foto 2, Acervo DOPS/GB, APERJ

A liberdade relativa da montagem em relação aos vestígios da história faz pensar no que disse Hartog sobre a autenticidade do documento. $\mathrm{O}$ termo "autêntico", que ele toma de empréstimo à língua judiciária, "remete apenas à proveniência, não ao conteúdo do documento" (2000). Bem antes dele, Foucault também havia se referido ao documento em termos de "proveniência" e não de origem. A historiografia, em sua vertente arqueológica, questiona o documento, por dentro, em sua arké, em seu "ponto de surgimento" (FOUCAULT, 1971, p. 154). Isso não quer dizer que vamos chegar, na montagem, a uma suposta origem das coisas ou a uma verdade sobre elas. Os fragmentos da foto de Maria Auxiliadora nua utilizados em Retratos de identificação não têm uma função probatória, assim como o cinema de arquivos náo é um arauto da verdade histórica. Mas ele também não pode fechar os olhos a esse horizonte, sob pena de colaborar com os processos de pilhagem dos arquivos e de interdição da verdade histórica. É nesse sentido que se espera do cinema uma tomada posição ao lado das imagens, a favor delas, abordando-as em sua materialidade documental, como faz o historiador, para quem a verdade histórica é, justamente, o horizonte de pesquisa.

A montagem se apresenta, entấ, nesse contexto complexo como o lugar de uma escrita específica da história, que combina uma política - ou seja, uma escolha de um método de abordagem da imagem do passado enquanto documento, como faz a historiografia - e uma poética, que não é privilégio da narrativa cinematográfica e que está presente também na narrativa elaborada pelo historiador de profissão. Paul Ricoeur, nos três tomos que escreveu sobre a relação entre tempo e narrativa, já chamava a atenção para o importante papel da atividade narrativa na transmissão da memória histórica (1985). Abordar uma imagem na montagem como um documento é uma maneira de encará-la como um objeto único, um vestígio do passado que levanta várias questôes. Qual é o valor de prova dessa imagem? De onde ela vem? Quando ela surgiu? A quais dispositivos de controle ela está ligada? Que desdobramentos da narrativa histórica ela torna possível? Reconhecer nas imagens um valor documental, uma autenticidade, não só evita a sua circunscrição a uma questão de conteúdo ou de verdade, como também as valoriza em sua dimensão formal, poética, estética. 
Ao se apropriar das imagens das agências de repressão, revelando seu extracampo político (o dispositivo de controle) ou explorando sua potencialidade estética (os detalhes imperceptíveis), a montagem de Retratos de identificação "expropria os expropriadores" (DEBORD, 1967). ${ }^{10}$ Arrancadas aos prisioneiros, as imagens da repressão, uma vez apropriadas pela montagem, são desviadas de sua função primeira e devolvidas ao presente como um problema atual. Essas imagens, feitas para a identificação do prisioneiro, quando confrontadas à montagem, passam a identificar seus próprios autores. Quando analisadas de perto, as fotografias de prisioneiros revelam informaçóes tanto sobre a polícia quanto sobre as pessoas nelas representadas. Submetidas à montagem, essas imagens passam a testemunhar sobre um ponto de vista da polícia sobre o prisioneiro. A recorrência, por exemplo, nos acervos do DOPS/GB, de fotos de pessoas nuas ou com ferimentos no rosto e no corpo, como é o caso de Maria Auxiliadora, traz revelaçôes sobre a pessoa fotografada, mas, também, sobre a base ideológica de fotografias que não precisam esconder marcas da tortura. Num regime de exceção em que a violação dos direitos humanos é a norma, o crime não é vivido pelo fotógrafo policial como um crime. $\mathrm{O}$ ato fotográfico insurge na foto por infração, como um prolongamento natural do ato de tortura: amarrado, algemado, despido, humilhado, ferido, o prisioneiro é ainda, nessas condiçóes, obrigado a posar para a objetiva, sob pena de ser executado. Onde a imagem se cala, a montagem mostra. E o que não é possível mostrar, como a nudez, o arquivo oral o diz, autorizando o close no documento.

Nessa disputa ao lado das imagens, a montagem coloca em evidência, dispóe as imagens de uma certa maneira, e em vez de sobrepor aos documentos um discurso externo sobre eles, ela mostra a mesa de trabalho. É o que fez, sistematicamente, Harun Farocki em seus filmes de arquivos, cuja montagem, em corte seco, oferece às imagens a ocasiáo de uma relação mais direta com o espectador, sem a mediação de efeitos especiais. As imagens da repressão carregam consigo vestígios de crimes ainda impunes e necessitam, por essa razão, de uma abordagem minimamente materialista, de maneira a tornar visíveis e/ou audíveis evidências históricas durante muito tempo ignoradas.

\section{A disputa entre as imagens}

$\mathrm{Na}$ mesa de montagem, diferentes fontes visuais e sonoras se confrontam ou, ao contrário, se associam na disputa pelas narrativas da história. As imagens agem umas sobre as outras por "atração"; do "choque dialético" entre duas imagens surge uma terceira imagem (EISENSTEIN, 1969); duas imagens podem também se justapor uma ao lado da outra, simplesmente, evidenciando o “intervalo" entre elas (VERTOV, 1972, p. 131). Uma imagem desmente outra imagem; um som ajuda outro som a romper com discursos pré-estabelecidos; um som e uma imagem se complementam ou se opóem um ao outro, por meio da ruptura sensível ou da continuidade imperceptível. A montagem, ora proibida (BAZIN, 1994), ora valorizada (GODARD, 1998), torna possível uma narrativa da história que se nutre da própria tensão entre cesura e sutura, atividades características desse tipo específico de escrita. 
Não se impõe cortes ou junçôes aos documentos da história impunimente. Cada efeito de montagem aplicado a uma imagem de arquivo age sobre ela e sobre nossa percepção do passado. A inscrição de um intervalo entre dois documentos - a tela preta, por exemplo, como acontece em Retratos de identificação - assinala uma fronteira entre eles e a singularidade de cada um. As imagens sonoras e visuais tornam-se plenas e fortes na "fronteira imperceptível que as separa" (DELEUZE, 1990, p. 66). Assim abordado, o documento resiste ao discurso único e se oferece ao presente como um "lugar de controvérsias" e de "narrativas alternativas" na escrita da história (RICOEUR, 2000). Da mesma forma que o historiador dos tempos atuais, o montador deve estar apto a comparar fatos e a aproximar documentos, bem mais do que a estabelecer uma reconstituição cronológica, tautológica e definitiva dos acontecimentos, ambição manifestada em muitos documentários históricos.

Levar em conta a autenticidade das imagens de arquivo não as reduz a um problema de conteúdo ou a uma função veritativa. Como lembra o cineasta Rithy Panh, grande conhecedor dos arquivos da história recente do Cambodja, o documento não é uma prova em si. "É a história que ele contém que é uma prova, mas essa história não se oferece espontaneamente. É preciso procurá-la.” (PANH, 2011, p. 306). Mais uma vez, a verdade é apenas o horizonte ético de quem trabalha com os arquivos numa perspectiva histórica. E um documento mentiroso não é menos autêntico do que um documento verdadeiro. Se a montagem cria as condições necessárias para uma real acareação entre as diferentes fontes documentais, um documento mentiroso testemunhará sobre a própria mentira. Vejamos um exemplo de disputa entre as imagens, pela verdade histórica.

Em Retratos de identificação, um documento forjado pela polícia foi uma peça importante na reconstituição da história do assassinato do militante Chael Schreier, preso no dia 21 de novembro de 1969, em companhia de Antônio Roberto Espinosa, comandante da VAR-Palmares, e de Maria Auxiliadora Lara Barcellos, militante da mesma organização. Levados para a PE da Vila Militar do Rio de Janeiro, os três foram barbaramente torturados por um grupo de oficiais e sub-oficiais do I Exército, com espancamentos, chutes, sevícias sexuais e choques elétricos. Chael não resistiu aos golpes e morreu após uma noite de torturas. O corpo foi levado para o Hospital Central do Exército, autopsiado sob ordem do diretor do hospital, o médico e general Galeno Franco, e entregue ao IML. Sem saber o que havia se passado na Vila Militar, o IML entregou o corpo e a autópsia à família e a morte do estudante foi imediatamente divulgada na imprensa nacional e internacional, frustrando as expectativas dos responsáveis pela morte do estudante de encobertarem o crime. Era a primeira denúncia pública de tortura no regime militar, divulgada em reportagem de capa da revista Veja no 66, de 10 de dezembro de 1969. O capitão Celso Lauria, encarregado do IPM da VAR e um dos chefes da equipe de tortura que matou Schreier, forjou, entáo, um documento afirmando ter havido "necessidade do emprego de energia física para efetivação da prisão, resultando daí as lesóes letais verificadas no corpo do militante". ${ }^{11} \mathrm{O}$ documento, assinado pelo capitão Lauria em 27 de fevereiro de 1970, três meses depois da morte do estudante, omite a existência do auto de autópsia, que constata, no entanto, 11 costelas quebradas, ruptura do mesocolo e do mesentério, hematomas em todo o corpo, diversas hemorragias internas e, até mesmo, implicitamente, assistência médica à tortura, ao se referir a "seis pontos de sutura na região mentoneira"." 
O capitão Lauria não imaginava que, 45 anos depois, um outro documento da polícia, além do laudo de necrópsia, viria se juntar ao dossiê de acusação e desmentir definitivamente sua falsa versão dos fatos. Pouco antes de ser levado para a Vila Militar, Chael fora fotografado no DOPS/GB, de frente e de perfil, com o torso nu, em plano aproximado na altura da cintura. Os negativos dessas fotos foram localizados no APERJ durante a pesquisa para o filme Retratos de identificação e, uma vez positivados, revelaram que o estudante não tinha nenhum ferimento da cintura para cima (fotos 3 e 4, Acervo DOPS/GB_APERJ). ${ }^{13}$ Confrontado a esses negativos, o documento forjado pelo torturador vem atestar os próprios métodos da repressão, trazendo à tona a história oficial que se tentava, então, fabricar. Esses negativos são o que a historiografia chama de "testemunhos não escritos", "involuntários", "testemunhos, apesar deles" (BLOCH, 1953, p. 38).
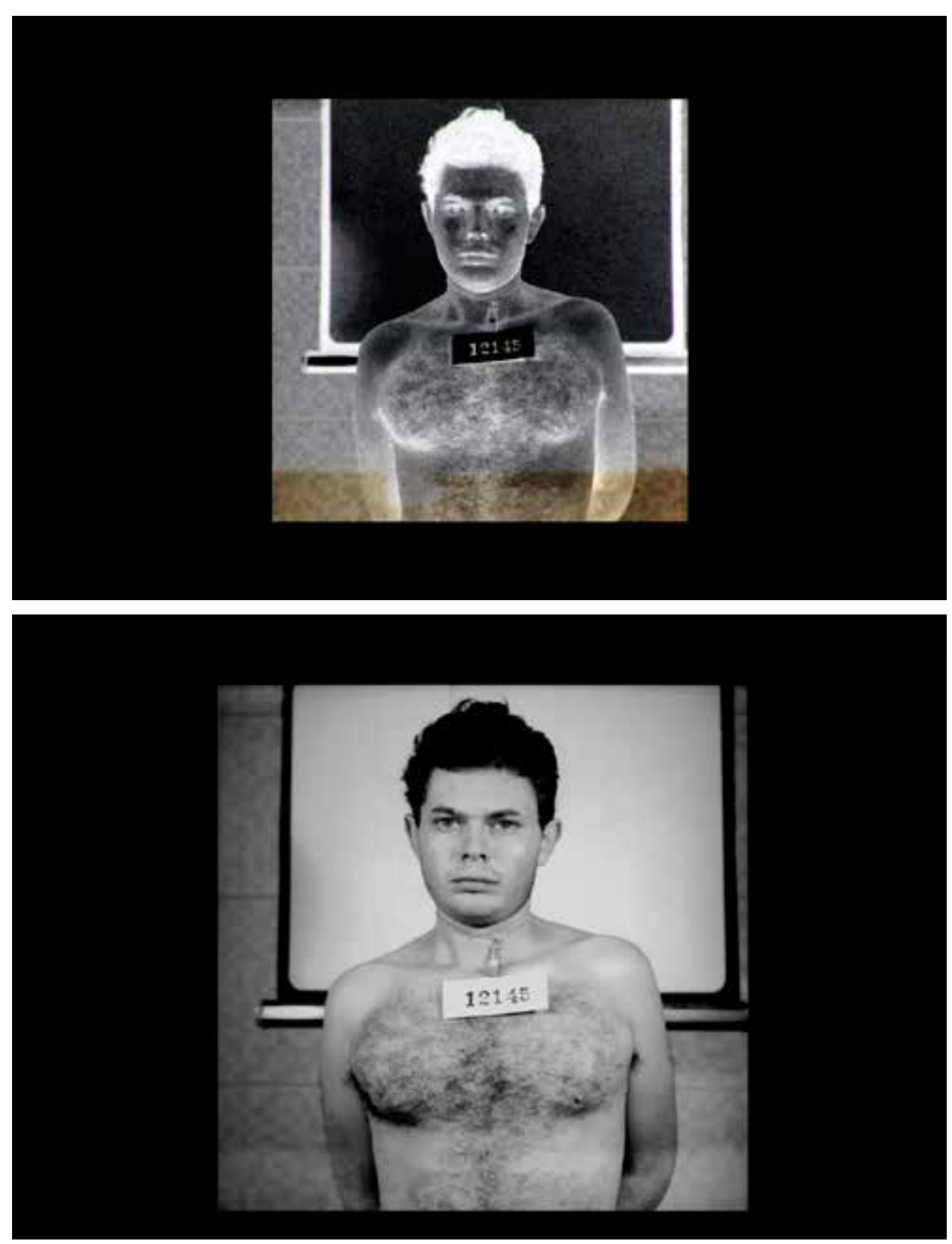

Fotos 3 e 4, Acervo DOPS/GB_APERJ 
Os acervos das agências de repressão do regime militar são compostos de imagens comprometedoras, que dificilmente retornarão ao convívio social de maneira espontânea. O Brasil vive, hoje, uma disputa acirrada pela elaboração de uma memória sobre o período da ditadura e o país sequer conhece o número exato de mortos da ditadura: 434 mortos e desaparecidos, números oficiais, ou 10 mil, números oficiosos, que incluem, nas estatísticas, a exterminação de negros, de pobres e, principalmente, de índios, no período? Os desaparecidos continuam desaparecidos, trabalhadores perseguidos ainda clamam por reparação simbólica, os torturadores ainda não foram julgados e se beneficiam de uma lei de anistia internacionalmente contestada, enquanto iniciativas de parlamentares de esquerda para a exclusão desse benefício sucumbem sob a pressão das Forças Armadas, apoiadas, no Congresso Nacional, por parlamentares de centro, direita e extrema direita. A impunidade naturaliza os crimes do passado e o esforço de uma parte da população em ampliar o debate é visto por uma outra parte com um misto de preconceito e desprezo. $\mathrm{O}$ desinteresse pela pesquisa de imagens nos arquivos da ditadura se verifica, inclusive, no meio universitário, onde o projeto que deu origem ao filme Retratos de identificação sofreu, no início, ataques revisionistas. $\mathrm{Na}$ mesma época, um oficial do Exército, a quem perguntei como a história dos crimes cometidos pela corporação era contada aos aspirantes à carreira militar, respondeu-me, simplesmente, que "os jovens estão mais interessados no amanhâ". A intimidação ideológica mergulha o presente nas trevas do esquecimento, em nome de um futuro que, sem o esclarecimento sobre os crimes do passado, jamais chegará. Num contexto tão generalizado de resistência à memória, como o brasileiro, é preciso ainda um grande esforço de montagem para tirar as imagens dos arquivos e colocá-las em circulação.

\section{Referências bibliográficas}

BAZIN, André. Qu'est-ce que le cinéma. Paris: Cerf, 1994.

BLOCH, Marc. Apologie pour l'histoire ou Métier d'historien. Cahiers des Annales, 3. Paris: Armand Colin, 1953.

DEBORD, Guy; WOLMAN, Gil. Mode d'emploi du détournement. Les Lèvres nues, Bruxelas, n. 8, p. 6, maio, 1956.

DEBORD, Guy. A Sociedade do espetáculo. Paris: Gallimard, 1992 (1967).

DELEUZE, Gilles. Pourparlers. Paris: Les Editions de Minuit, 1990.

EISENSTEIN, Sergei. Reflexóes de um cineasta. Rio de Janeiro: Zahar, 1969.

ESPINDOLA, Claudia. A preservação de documentos do DOPS no APERJ. Acervo, v. 23, Rio de Janeiro, 2010, p. 115-124.

FOUCAULT, Michel. Nietzsche, la généalogie, l'histoire. In: Hommage à Jean Hyppolite. Paris: PUF, 1971.

GODARD, Jean-Luc. JLG par JLG. Tome 1 (1950-1984). Paris: Cahiers du cinéma, 1998.

HARTOG, François. Le témoin et l'historien, Gradhiva n. 27, 2000. 
MOTTA, Rodrigo Patto Sá. História, Memória e as disputas pela representação do passado recente. Patrimônio e Memória. São Paulo, Unesp, v. 9, n.1, p. 56-70, janeiro-junho, 2013.

PANH, Rithy. L'élimination. Paris: Grasset, 2011.

RICCEUR, Paul. La mémoire, l'histoire, l'oubli. Paris: Seuil, 2000.

RICEUR, Paul. Temps et récit. Tome 3. Le temps raconté. Paris: Seuil, 1985.

TORRES MAGALHÃES, Fernanda, $O$ suspeito através das lentes. O DEOPS e a imagem da subversão (1930-1945), Fapesp-HumanitasImprensa Oficial, São Paulo, 2008.

VERTOV, Dziga. Articles, journaux, projets. Paris: Union Générale Editions, 1972.

\section{Notas}

1. As questôes retomadas nesse artigo foram apresentadas no seminário "Imagens em disputa" (PUC-Rio, 2015).

2. A documentação do DOPS/GB está, hoje, sob a guarda do Arquivo Público do Estado do Rio de Janeiro (APERJ). Há, também, no filme, documentos provenientes do SNI, guardados no Arquivo Nacional, e do Cenimar, o órgão de repressão da Marinha, localizados no Superior Tribunal Militar.

3. Além das fotos de homens com o torso nu, encontramos também nos arquivos policiais muitas fotos de homens e mulheres de corpo inteiro, totalmente despidos, bem como fotos de mulheres apenas com calcinha. Trata-se, nesses casos, de fotos tiradas durante os exames de corpo de delito, aos quais os prisioneiros eram geralmente submetidos ao serem banidos do país. Mas como as mulheres também eram com frequência torturadas sem roupa e fotografadas durante a tortura, é possível que também exista, nos arquivos, retratos de prisioneiras nuas, tirados durante os interrogatórios.

4. Embora seja o primeiro cartaz da série produzida pela polícia, vê-se no canto direito inferior o número " 2 ", numeraçấo, ao que tudo indica, decorrente de superstiçốes dos militares, que evitavam os números ímpares. Todos os cartazes da série que encontramos até entâo têm números pares.

5. Sobre o processo de tratamento dos acervos do DOPS pelo Arquivo Público do Estado do Rio de Janeiro (APERJ), no âmbito do projeto Memórias reveladas, ver o artigo de Cláudia Espíndola (2010). Hoje é possível consultar os arquivos das agências de repressão sem a necessidade de obter uma autorização prévia dos prontuariados ou de seus familiares para isso. Em caso de divulgação dos documentos, é preciso a cessão de direito à imagem da pessoa neles mencionada ou representada. Sobre essa questão, remetemos ao artigo de Rodrigo Patto Sá Motta (2013).

6. Em diligência do Ministério Público Federal no Hospital Central do Exército, em novembro de 2014, foram encontrados prontuários de prisioneiros entre 1940 a 1969 e 1973 a 1983, cuja existência havia sido ocultada da Comissão Nacional da Verdade. Foi também encontrada no local uma pasta com nomes, fotografias e informaçóes sobre os membros da CNV e da CNV do Rio, o que mostra a permanência das atividades do serviço de informação do exército. http://www.cnv. 
gov.br/outros-destaques/565-exercito-ocultou-documentos-procurados-pela-cnvem-hospital-do-rio.html

7. Sobre a documentaçáo encontrada na casa do coronel Molinas Dias e entregue à CNV: http://www.cnv.gov.br/component/content/article/41-documentos-citados-novolume-i-do-relatorio/618-documentos-citados-capitulo-13.html

8. Sobre a morte do coronel Malhães: http://www.cnv.gov.br/outros-destaques/477-notaoficial-sobre-a-morte-do-coronel-paulo-malhaes.html

9. Em 1970, Chris Marker havia realizado On vous parle du Brésil: Tortures, curta metragem da série On vous parle, em que os 15 prisioneiros trocados pelo embaixador norte-americano falam, já no exílio, em Cuba, sobre as torturas sofridas nos poróes da ditadura.

10. Já nos anos 1950, Debord colocava em pauta a dimensão política da retomada das imagens na mesa de montagem: "o mundo já foi filmado. Trata-se agora de transformálo" (DEBORD; WOLMAN, 1956).

11. Inquérito Policial Militar da VAR-Palmares, documento do acervo Polícias Políticas do Arquivo Público do Estado do Rio de Janeiro (APERJ).

12. Autópsia de Chael Charles Schreier, documento do acervo Polícias Políticas do APERJ.

13. A série de fotografias da prisão conjunta de Chael Schreier, Antônio Espinosa e Auxiliadora Barcellos é formada por seis retratos e seus respectivos negativos, dois de cada um dos prisioneiros, de frente e de perfil. A série foi mostrada na audiência pública da Comissão Nacional da Verdade de 24 janeiro de 2014, quando o filme ainda estava em fase de montagem. Site consultado em 03/04/2016:

14. http://www.cnv.gov.br/outros-destaques/423-fotos-exibidas-em-audiencia-da-cnvdesmontam-versao-do-exercito-para-morte-de-estudante.html 